\title{
A news update from the students and new professionals group
}

\author{
Angela M. Lees ${ }^{1} \cdot$ Daniel J. Vecellio² $\cdot$ Yuliya Dzyuban ${ }^{3}$
}

Received: 18 January 2021 / Revised: 9 February 2021 / Accepted: 10 February 2021 / Published online: 30 November 2021

(c) ISB 2021

Update

We would also like to take this opportunity to formally introduce ourselves as the 2020 to 2023 SNP executive committee: Daniel Vecellio, Yuliya Dzyuban and Angela Lees, as your SNP secretary, communications director and chair. On behalf of the SNP, we would like to take this opportunity to sincerely thank Hamed Mehdipoor for leading the SNP group throughout the previous triennium (2017-2020). We also extend our gratitude to Andrew Leung (research chair) and Britta Jänicke (webmaster) for their contributions to the SNP executive board over the previous three years. We sincerely thank you all for your time and dedication to the SNP over the previous triennium (2017-2020). We would like to extend our thanks to the previous SNP chairs: Kate Bassil, Simon Gosling and Jennifer Vanos. The dedication by you all has allowed the SNP group to become what we experience the SNP as today, and for that on behalf of all SNP members past and present, we offer you our sincerest appreciation for your hard work and continued support and encouragement of the SNP group. We, the SNP, simply would not be here without you.

In line with those who have come before us, we would like to offer a brief reminder of the SNP's history. The first meeting of the SNP occurred at the $18^{\text {th }}$ International Congress of Biometeorology in Tokyo, Japan, during 2008 (Kate Bassil). This was followed by the SNP's second meeting at the $19^{\text {th }}$ International Congress of Biometeorology held in Auckland, New Zealand, during 2011 (Simon Gosling).

Angela M. Lees

angela.lees@une.edu.au

1 School of Environmental and Rural Science, University of New England, Armidale, NSW 2350, Australia

2 Center for Healthy Aging, College of Health and Human Development, Pennsylvania State University, PA, University Park, USA

3 Office of Core Curriculum, Singapore Management University, Singapore, Singapore
Three years later, the $20^{\text {th }}$ International Congress of Biometeorology was held in Cleveland, OH, USA (Jennifer Vanos) during 2014. Incidentally, this Congress was Angela and Daniel's first introduction to ISB and the SNP group. The SNP then met again for a workshop during 2017, when Durham hosted the $21^{\text {st }}$ International Congress of Biometeorology. The $22^{\text {nd }}$ International Congress of Biometeorology that was to be held in Jaboticabal, Brazil, was initially scheduled for 2020; however recently due to the global impacts of COVID-19, the ISB recently held the congress as a virtual event in September 2021.

The SNP as a group has made considerable progress given that the group has only been established for the last 12 years. This is particularly evident given the development of International Workshops and the publication of two SNP special issues within our journal (Gosling, 2014, 2018), the International Journal of Biometeorology, and a third special issue currently in progress. The international workshops commenced three years after the $19^{\text {th }}$ International Congress of Biometeorology, where during 2014 a group of SNP members developed and attended the $1^{\text {st }}$ International SNP Workshop on 'Biometeorology and Applied Synoptic Climatology' in Vindlen, Sweden (Vanos, 2018). The $2^{\text {nd }}$ International SNP workshop was held in Norfolk (USA) during 2016 with a focus on 'Enhancing the Teaching and Learning of Biometeorology in Higher Education' (hosted by Michael J. Allen). More recently, the $3^{\text {rd }}$ International SNP workshop on 'Investigating Knowledge Gaps and Technology Opportunities for Sensing the Health Effect of Weather and Climate Change' was held in Enschede, The Netherlands (hosted by Hamed Mehdipoor) in December 2019, which was Yuliya Dzyuban's introduction to the SNP. These workshops would not have been possible without the support provided by ISB and the Tromp Foundation, in addition to the hosting institutions, as such we extend our gratitude to those that have supported these workshops. All of the aforementioned workshops have resulted in formal outputs in the form of peer-reviewed publications specifically those 
by Gosling et al. (2014), Hondula et al. (2014), Dixon et al. (2016), Allen et al. (2017), Mehdipoor et al. (2017), Perkins et al. (2017) and Anderson et al. (2021). It is clearly evident from these achievements that the SNP continues to go from strength to strength. However, the value of the SNP and the international workshops extends beyond formal peerreviewed publications and international workshops. The SNP strives to establish extensive international networks and mentoring, presenting unlimited opportunities to collaborate across our interdisciplinary science. We are an extraordinarily diverse group and this is certainly reflected by the International SNP workshops and SNP special issues. However, in our opinion, the diversity of our group is a reflection of the diversity of ISB. Furthermore, it is a reflection of the diversity of our interdisciplinary science, allowing for the collaboration of diverse disciplines including, but not limited to, meteorology, geography, biology, mathematics and statistics, environmental science, urban climatology, epidemiology, health and physiology (Gosling et al., 2014), in plants, animals, humans and the world around us. In addition, it is a reflection of who we are as people. As such, we are incredibly grateful for the opportunity to lead this diverse and astonishingly talented group of young scientists.

The members of ISB, particularly those in leadership roles, have provided support to the SNP and ISB continues to be committed to the SNP by supporting the professional development of our members (Gosling, 2018). The support of ISB occurs not only via the development of our international workshops but also through encouraging publishing the aforementioned SNP special issues, that highlight the talent and diversity of the SNP in addition to biometeorological studies. This is important for both ISB and the SNP, as some of our members will likely represent ISB in future years (Gosling, 2018; Vanos, 2018). In support of this, many of the SNP members have gone on to leadership roles within ISB, notably: Cameron Lee, Managing Editor of the International Journal of Biometeorology; Simon Gosling, previous Europe Councillor and SNP chair; Jennifer Vanos, previous North America Councillor, SNP chair (2014-2017), and current Vice President: Michael Allen, Secretary and Treasurer; Yuliya Dzyuban, Asia Councillor; Adam Kalkstein, North America Councillor; Sheila Nascimento, Animal Commission Chair; and Angela Lees, Oceania Councillor and SNP Chair. This highlights the commitment to mentorship and engagement that ISB members have towards members of the SNP and the capability development that exists within ISB.

Moving forward, we will strive to expand the SNP network and increase global participation through creating local representation in the SNP and ISB globally. One way ISB endeavours to engage globally is via its regional councillor's (Jennifer Fitchett, Africa; Yuliya Dzyuban, Asia; Tanja Cegnar, Europe; Fabio Luix Teixeria Goncalves, Latin and South America, Adam Kalkstein, North
America; and Angela Lees, Oceania), we encourage you to reach out to your regional councillor to expand your networks and identify opportunities to engage with other biometeorologists in your region. For the SNP, we will aim to diversify our activities and outputs from the SNP group, and expand the group's mentorship role to better support upcoming generations of scientists and practitioners. We will collaborate with other international multi and trans-disciplinary networks to better leverage resources in achieving common goals towards increasing the awareness of biometeorology and building a more sustainable future. If you have any suggestions or communications for the SNP group, we encourage you to contact us as we are here to represent you and we cannot do this without you. We strongly encourage you all to be active members within the SNP group and further into ISB. We look forward to getting to know you over the current triennium and representing you in our endeavours over the next three years.

\section{References}

Allen MJ, Vanos J, Hondula DM, Vecellio DJ, Knight D, Mehdipoor H, Lucas R, Fuhrmann C, Lokys H, Lees A, Nascimento ST, Leung ACW, Perkins DR (2017) Supporting sustainability initiatives through biometeorology education and training. International Journal of Biometeorology 61((Supplement) 1):93-106. https://doi.org/10.1007/s00484-017-1408-z

Anderson V, Leung ACW, Mehdipoor H, Jänicke B, Milošević D, Oliveira A, Manavvi S, Kabano P, Dzyuban Y, Aguilar R, Agan PN, Kunda JJ, Garcia-Chapeton G, de FrançaCarvalhofonsêca V, Nascimento ST, Zurita-Milla R (2021) Technological opportunities for sensing of the health effects of weather and climate change: a state-of-the-art-review. International Journal of Biometeorology. https://doi.org/10.1007/s00484-020-02063-z

Dixon PG, Allen M, Gosling SN, Hondula DM, Ingole V, Lucas R, Vanos J (2016) Perspectives on the synoptic climate classification and its role in interdisciplinary research. Geogr Compass 10(4):147-164. https://doi.org/10.1111/gec3.12264

Gosling SN (2014) New insights into biometeorology. Int J Biometeorol 58(2):101-102. https://doi.org/10.1007/s00484-014-0793-9

Gosling SN (2018) Additional new insights into biometeorology. Int J Biometeorol 62(1):1-2. https://doi.org/10.1007/ s00484-017-1478-y

Gosling SN, Bryce EK, Dixon PG, Gabriel KMA, Gosling EY, Hanes JM, Hondula DM, Liang L, Bustosmaclean PA, Muthers S, Nascimento ST, Petralli M, Vanos JK, Wanka ER (2014) A glossary for biometeorology. International Journal of Biometeorology 58(2):277-308. https://doi.org/10.1007/s00484-013-0729-9

Hondula DM, Vanos JK, Gosling SN (2014) The SSC: a decade of climate-health research and future directions. Int J Biometeorol 58(2):109-120. https://doi.org/10.1007/s00484-012-0619-6

Mehdipoor H, Vanos JK, Zurita-Milla R, Cao G (2017) Short communication: emerging technologies for biometeorology. Int J Biometeorol 61(1):81-88. https://doi.org/10.1007/ s00484-017-1399-9

Perkins DR, Vanos J, Fuhrmann C, Allen M, Knight D, Lee CC, Lees A, Leung A, Lucas R, Mehdipoor H, Tavares Nascimento S, Sheridan S, Spencer J (2017) Enhancing the teaching and 
learning of biometeorology in higher education. Bulletin of the American Meteorological Society 98(9):ES239-ES242. https:// doi.org/10.1175/BAMS-D-16-0343.1
Vanos JK (2018) ISB news from the Chair of the Student and New Professionals Group. Int J Biometeorol 62(1):139-140. https:// doi.org/10.1007/s00484-015-0981-2 